Article

\title{
Pathways of Conflict: Lessons from the Cultivation of MON810 in Germany in 2005-2008 for Emerging Conflicts over New Breeding Techniques
}

\author{
Beate Friedrich \\ Institute of Sustainability Governance (INSUGO), Leuphana University Lüneburg, 21335 Lüneburg, Germany; \\ beate.friedrich@uni.leuphana.de
}

Received: 30 November 2019; Accepted: 18 December 2019; Published: 23 December 2019

check for updates

\begin{abstract}
The paper uses qualitative interviews and document analysis to examine conflicts over plant and animal breeding techniques from the perspectives of Social and Political Ecology. It asks how past conflicts over genetically modified organisms (GMOs) can inform understandings of possible trajectories of emerging conflicts over new breeding techniques (NBTs) such as CRISPR/Cas genome editing. Case studies of conflicts in three areas where the transgenic maize MON810 was cultivated in Germany from 2005-2008 show that the escalation of conflict coincided with the first tangible presence of these already controversial organisms in the rural landscape. Location-specific interlinkages between discursive and material dimensions gave rise to different pathways of conflict in the three areas studied. These empirical results inform the analysis of emerging conflicts over NBTs in Germany and the United Kingdom. The future of NBTs in both countries is still open, and the divergence of regulatory frameworks in Europe could lead to the development of 'NBT hotspots' located in particular European countries, provoking an escalation of conflict in areas where commercial application takes place. The paper concludes by examining the potential for a politicization of future conflicts to encompass wider issues related to the transformation of agricultural systems towards sustainability.

Keywords: agriculture; conflicts; Genetically Modified Organisms (GMOs); MON810 in Germany; New Breeding Techniques (NBTs) in Germany and the United Kingdom (UK); social ecology; society-nature relations; political ecology; precautionary principle; sustainability transformation
\end{abstract}

\section{Introduction}

The genetic manipulation of plants and animals and their use in agriculture and food production are highly contested, and conflicts have accompanied the introduction of transgenic organisms wherever this has occurred (e.g., [1-4]). Today, there are some crops that are predominantly cultivated as genetically modified organisms (GMOs), including soybean and cotton (in both cases, GMOs account for around three-quarters of total global cropland), as well as maize and canola (both around one-third of the global cropland) [5]. However, because of the perceived likelihood of negative environmental, social, and economic impacts, as well as possible health risks, many farmers and consumers, especially in Europe, are still in favor of GMO-free agriculture [6,7]. In the European Union (EU), regulations governing the use of GMOs are based on a policy of 'coexistence'. This policy envisages the parallel existence of agriculture with and without GMOs [8]. However, individual genetically modified (GM) crop varieties still have to be approved for commercial cultivation, and to date, only a few have received such approval; these include the two maize varieties 'Bt176' and, 'MON810', and the starch potato 'Amflora'. To date, these GM crops have been cultivated in quite small amounts in only a few European countries. Today, MON810 is the only GM plant that is approved for cultivation in the EU, 
and it is widely cultivated in Spain and, to a limited extent, in Portugal. However, the vast majority of croplands in the EU are GMO-free [5].

The paper asks why and how conflicts over GMOs escalated in the past and what these can teach us about the possible trajectories of emerging conflicts over new breeding techniques (NBTs) such as CRISPR/Cas genome editing. It focuses on an area where there is an evident need for further research, i.e., conflicts over the short and long-term societal and social-ecological consequences of GMOs and NBTs [9]. The paper presents the results of an empirical study of conflicts that occurred in areas where the transgenic maize MON810 was cultivated in Germany between 2005 and 2008. These empirical results inform the analysis of emerging conflicts over NBTs in Germany and the United Kingdom (UK). The paper is intended to contribute to debates in Political and Social Ecology. Two hypotheses underpin the approach adopted in this study. The first is that conflicts over NBTs are "writing the same old story" [10] by running through the same repertoire of issues that were raised during previous conflicts over GMOs. The second assumption is that current low-level conflicts over NBTs will continue and intensify, and come to a head at the point when decisions have been made by government ministers about the use of the products of NBTs by farmers, and about their consumption.

NBTs have been developed in recent years, and the products of NBTs differ technically from 'first generation' GMOs. While 'first generation' GMOs include foreign genetic material from different organisms, genome editing techniques, such as CRISPR/Cas, involve the selective alteration of DNA at certain parts of the genome by point mutations or the excision or incorporation of new sequences. A key area of controversy is whether the product or the process is relevant for assessment and approval, because the products of NBTs are sometimes not distinguishable from those of conventional breeding methods [11]. The issue of detection remains controversial, and there have been calls for further research on this topic before NBTs are approved for commercial application [12]. Furthermore, while there was a legal obligation for developers and users of MON810 to limit 'contamination', i.e., the spread of transgenes, some products of NBTs incorporate 'gene drives', which are specifically designed to enable a particular genome to be propagated throughout a population [13]. Possible applications of NBTs in agriculture include the development of climate-adapted and disease-resistant plant varieties or of animal breeds that are better adapted to production processes [14,15]. It has even been suggested that NBTs could be used to support biodiversity conservation [16]. Proponents consider the procedures to be faster, more precise, more effective, and thus significantly less expensive than classical genetic engineering techniques, and the hope has been expressed that this might make them more accessible for use by small and medium-sized enterprises. At the same time, NBTs have given rise to a number of concerns, e.g., regarding risks associated with side effects and off-target effects, as well as the possibility of negative socio-economic impacts, and there is an ongoing debate about responsible regulation [17-22]. Possible conflicts of interest in research and regulation are also an issue, for example, when research is publicly funded [23,24]. At the EU level, there were months of negotiations over whether NBTs should be treated as conventional breeding methods or as a new type of genetic modification. In July 2018, the European Court of Justice (ECJ) ruled that organisms produced using the new techniques should be regulated as GMOs in the EU; they thus fall within the statutorily-defined scope of all relevant regulations and directives [25]. On the one hand, this ruling brought legal clarity. On the other hand, it remains controversial, and discussions about the future of NBTs are still ongoing [26]. Voices have been raised (e.g., those of business organizations with interest in using the techniques) demanding more "innovation friendly" [27] regulations that would require less complex approval procedures. Fourteen EU member states have called for a "unified approach" on the EU level [28] that could lead to a more liberal approach, exempting some NBTs from GMO regulation. Also unclear is how the ruling could be applied to imported goods, as NBTs are already in use in some countries, such as the USA, where some products and product groups produced using NBTs cannot be distinguished using currently available technologies from those of conventional agriculture [21]. On 8 November 2019, the European Commission was requested by the EU member states to study "the status of novel genomic techniques under Union law" [29]. 
Germany and the United Kingdom (UK) are relevant cases for comparative analysis in this area. In both countries, there are discussions currently ongoing on the regulation of NBTs, with contradictory proposals being advanced. In the UK, those discussions are taking place in the context of current political developments, i.e., Brexit. Until now, the UK has been covered by the European GMO legislation. Following the vote to leave the EU, it remains an open question how the UK will choose to regulate the cultivation and release of GMOs in the future [30-34]. The experience of conflicts over the cultivation of MON810 in Germany can yield insights into how future conflicts over the commercial application of NBTs might play out, including in the UK, where there have been conflicts about experimental releases of GMOs but, to date, they have not been commercially grown (see Section 2).

The structure of the remainder of the paper is as follows. Section 2 presents the methodology adopted in the study and the conceptual framework that underpins it. Section 3 presents the results of an empirical study of conflicts that occurred in areas where the transgenic maize MON810 was cultivated in Germany between 2005 and 2008, followed by an analysis of the current situation of NBT conflicts in Germany and the UK. Section 4 discusses the significance of these findings for possible trajectories of future conflicts over NBTs. Briefly, the results show that conflicts over MON810 escalated when a high level of national and international interest in the topic coincided with the visible and tangible presence of the controversial organisms at sites earmarked for their cultivation. Conflicts over NBTs have not yet escalated to this level in Germany or in the UK but may well do so when the crucial step is taken to approve commercial application of the technology. The paper concludes with a summary of the significance of the findings in the light of the need for transformation of agricultural systems towards sustainability.

\section{Material and Methods}

The empirical research reported in this study analyzed conflicts over the cultivation of MON810 in Germany between 2005 and 2008 and describes the current status of conflicts over NBTs in Germany and the UK. In Germany, the GM maize MON810 was cultivated commercially between 2005 and 2008, before being banned in spring 2009 [35]; and the GM potato Amflora was cultivated between 2010 and 2011, before the withdrawal of the product from the market [36]. In these periods, demonstrations, acts of civil disobedience, and other forms of protest took place, especially in areas where the cultivation of these GMOs was taking place or was planned $[37,38]$. These actions represented an intensification of protests against the cultivation of the maize Bt176 and experimental releases of GM plants that had been taking place since the 1990s [39]. In the UK, there have also been intense conflicts over the experimental release of several GM plants [39,40]. However, there has been no widespread commercial cultivation of GMOs in the UK. This is because none of the approved organisms is suitable for use in the UK, due in part to the absence of the pests these GM varieties are designed to resist [41]. In addition to cultivation and experimental release of GM plants, their products have been imported to both Germany and the UK (mostly for animal feed), while GM animals are not approved for import or farming in the EU. The current situation is that in Germany no commercial cultivation or experimental release of GMOs has occurred since 2012. The UK is divided: In England, MON810 is still approved for commercial cultivation but has not yet been cultivated. Scotland, Wales, and Northern Ireland opted out of GMO cultivation after being given this opportunity to do so by the EU. There are currently several GM crop trials ongoing or approved in the UK [30]. In the UK, approval has been given for two NBT field trials, one of which has already been carried out (before the ECJ ruling). In Germany, research on NBTs has so far been confined to laboratories; field trials with a rapeseed marketed by the US company Cibus were approved, but not proceeded with [42-45].

To analyze conflicts over MON810, the study examined three contrasting cases of conflicts in three regions of Germany. The research was carried out ex-post in the period 2009-2012, when MON810 had already been banned and the intense conflicts had subsided. The cases were selected using quantitative data from the German location register ("Standortregister"), where farmers were legally obliged to identify areas where they intended to cultivate GM crops. The register was examined online on the 
website of the Federal Office of Consumer Protection and Food Safety (BVL) [46]. The location register shows that GM crop production was planned in more than 40 municipalities in 2005, and by 2008 the number of municipalities had more than doubled. Two criteria were used to select case studies for this research. Firstly, cases were selected where landowners went ahead with their plans and actually cultivated (or attempted to cultivate) GM crops. In other words, sites where the initial registration was not followed up on were omitted from this study. Secondly, cases were chosen where there was evidence that protests had taken place. In order to capture regional impacts of conflicts and enable comparison among the case studies, the unit of analysis in each case was the district (Landkreis) in which the cultivation was planned and/or took place. The three districts chosen were: (1) Kitzingen in the north of the Federal State of Bavaria, where MON810 was grown continuously on a small scale (on cultivated areas up to 24 ha) between 2005 and 2008 and where there were plans to cultivate it in 2009; (2) Lüchow-Dannenberg in Lower Saxony in north Germany, where the cultivation of MON810 was planned in just one year, in 2008, and could not take place due to protests; and (3) Oberhavel in Brandenburg in East Germany, where MON810 was grown continuously on a large scale (on area up to $936 \mathrm{ha}$ ) from 2005 to 2008 and where there were plans to cultivate it in 2009 [46]. Thus, the cases differ in terms of whether or not cultivation took place, the period of cultivation, and the scale of cultivation (i.e., the size and number of cultivation sites) and provide insights into conflicts over commercial cultivation of GMOs under various circumstances. There was also variation in contextual factors, including type of agricultural system, farm size and management structure (see Supplementary Material 1), and location. The three cases were located in three different federal states (Länder), with representation from both former West and East Germany and from north and south Germany.

The empirical analysis comprised three stages: (1) The first consisted of preparatory internet research and informal conversations with experts and stakeholders. (2) Field research in the second stage consisted of 34 semi-structured problem-centered interviews (referred to below by number as interviews I1-I34, see Supplementary Material 2). Interviews were conducted by telephone or in person and were recorded, amounting to a total of $26 \mathrm{~h}$ of recordings and 680 pages of transcriptions. The interviewees were chosen by snowball sampling and included male and female proponents and opponents of GMOs, farmers (from different types of farms), local residents, and representatives of regional and national actors. The interview transcripts were supplemented by memos of short ad hoc talks with people encountered during the three to four on-site visits per region (referred to below as M1-M10 and comprising 12 pages of material). All texts were analyzed by open coding, axial coding, and selective coding [47]. (3) During and after the field research, relevant printed material that could be used to validate the results of the interviews was collected, including articles and letters to the editor in local newspapers of the three districts, leaflets, press releases, blogs, and websites (of locally-based and regional and national organizations on both sides of the debate), as well as a few articles from national newspapers. This material amounted to a total of 350 text pages, most of which refer to the period between 2005 and 2009, but with occasional references to periods before and after. Text material in the empirical corpus was complemented by relevant films and photos that were found online.

The results obtained from the empirical research underpinned the subsequent analysis of emerging conflicts over NBTs in Germany and the UK. This part of the analysis consisted of a literature review and an analysis of documents published by actors who have a direct impact on agricultural practice, i.e., through regulation and/or by shaping public discourse on agricultural practice. These actors included government agencies in the UK and Germany, the National Farmers' Union (UK) and Deutscher Bauernverband (German Farmers' Association), the Landworkers' Alliance (UK) (supplemented by a document from La Via Campesina of which the Landworkers' Alliance is a member), and Arbeitsgemeinschaft bäuerliche Landwirtschaft (German Small Farmers' Organisation), anti GMO organizations from the UK and Germany, the environmental NGOs Friends of the Earth (UK) and BUND (Germany), pro-GMO lobby organizations and plant breeders, and organizations from both countries representing organic agriculture (supplemented by a document from IFOAM/Organics international). A total of 34 documents that were all accessible online (mostly on the organizations' 
websites, i.e., position papers or press releases) were selected for analysis (see Supplementary Material 3). The documents were analyzed using structured content analysis [48,49]. "General opinion on NBTs" and "key issues mentioned in the documents" were used as main categories.

The design of the investigation was guided by perspectives from Political and Social Ecology [50-52]. For the analysis of conflicts over GMOs and NBTs, these perspectives give vital insights. They help to broaden the scope of analysis, and to show how political, economic, social, and socio-ecological dimensions of conflicts are linked, because their focus is on the political processes and power relations that are associated with environmental conflicts. From the perspective of Social Ecology, 'nature' is understood as something that is constantly shaped and (re-)produced by society in historically changing ways but is (analytically) distinct from society [53]. This helps to understand the role of GMOs and NBTs in societal conflicts by highlighting their dual existence as both technical products, on the one hand, and living organisms, i.e., 'nature', on the other. Both theoretical perspectives question the possibility of a total domination of 'nature' by humans: On the one hand, 'nature', including the 'nature' in which agriculture functions, is produced (and undermined) socially; on the other hand, it remains a non-identical, living 'other'. For the conflicts over GMOs and NBTs, this means that the (re-)production of 'nature' can often become the object of conflict and conflictive action, because, by using GMOs or NBTs (or not) humans actively change and recreate 'nature' and can choose to do so in different ways. At the same time, the (re-)production of 'nature' is the product of these conflicts, because their development and outcomes determine how 'nature' is (re-)produced, i.e., with or without GMOs or NBTs. On the one hand, environmental conflicts, including conflicts about GMOs and NBTs, have material components; ecosystems are changed. On the other hand, the conflicts are not only about processes in ecosystems, but also about the different narratives that are used to portray them and how these narratives are interpreted. These socio-ecological causes and the consequences of those contests and conflicts also raise ethical considerations. These dimensions can be distinguished analytically but are intertwined in practice.

The conflicts analyzed in this study raise profound questions about how crops should be grown and 'nature' (re-)produced; the scope of the debates is thus far wider than the possible adverse material effects of GMOs on ecosystems and on human health. Conflicts over GMOs are also about processes of concentration of power in agrifood systems. Questions about knowledge production, political regulation, and participation that arise during the conflicts are inseparably linked to attempts to maintain or contest these power structures. At a deeper level, the conflicts express contradictory visions of the future, not only of agriculture but also of society in general. In this respect, Political and Social Ecology can provide insights into how different aspects of the conflicts over GMOs are related to these wider issues, as well as a critical appreciation of how they are interpreted by the actors involved. Within Political and Social Ecology, a critical and emancipatory understanding of sustainability places special emphasis on the concepts of caring and precaution $[17,51,54]$. These can be used as guiding principles for negotiating the future of emerging technologies by focusing attention on the interlinkages between material and discursive dimensions of the conflict, and on ethical considerations, including intergenerational justice.

\section{Results}

Section 3.1 summarizes information obtained about the conflicts over MON810 in the three districts that were chosen as case studies (Sections 3.1.1-3.1.3). Section 3.2 describes current conflicts over NBTs in Germany and the UK.

\subsection{Conflicts over MON810 in Germany}

The three cases give an overview of possible pathways of conflict in the areas where controversial breeding techniques are used commercially. The results demonstrate the variety of both discursive and material dimensions of conflict actions, issues, and outcomes. Specifically, conflict actions included the cultivation of MON810 and, at an earlier stage, its announcement in the location register [46]; 
the publication of position statements (written or oral); the organization of demonstrations, vigils, and other forms of protests; the filing of complaints in court; and acts of civil disobedience such as the destruction of maize plants. While the immediate causes of conflicts were often problems involved in applying the EU's policy of "coexistence", the actors involved viewed these problems within the framework of wider debates on the future of agriculture (or even broader political issues). At the same time, there was evidence of an individualization or even personalization of the conflicts. Personal and political issues became intertwined. On the level of discourse, tensions emerged between legitimacy and legality of transgenic maize. Socially, the conflicts led to tensions between neighbors, between tenants and landowners, and between 'external' actors and local farmers and residents. Overall, conflicts were perceived by the actors involved as a break with the status quo that had a productive, but also a destructive, dimension; the cultivation of MON810 changed the communities where it took place. Table 1 gives an overview of the central characteristics of the conflicts.

Table 1. Central characteristics of MON810 conflicts in the three study regions.

\begin{tabular}{|c|c|c|c|}
\hline & Kitzingen & Lüchow-Dannenberg & Oberhavel \\
\hline Agricultural structure ${ }^{1}$ & Small-scale & Medium-scale & Large-scale \\
\hline Local opposition & Strong & Strong & Weak \\
\hline $\begin{array}{l}\text { Presence of external } \\
\text { actors }\end{array}$ & Yes & Yes & Yes \\
\hline Special features & $\begin{array}{l}\text { Intense polarization and } \\
\text { politicization of the } \\
\text { conflict; long-lasting } \\
\text { coalitions formed }\end{array}$ & $\begin{array}{l}\text { Personalization of the conflict; } \\
\text { importance of local cultural } \\
\text { values; MON810 viewed as } \\
\text { an 'invasion that was defeated' }\end{array}$ & $\begin{array}{l}\text { The region became the 'stage' } \\
\text { for the national-level conflict } \\
\text { over agricultural } \\
\text { biotechnology }\end{array}$ \\
\hline Outcome of conflict & $\begin{array}{l}\text { MON810 cultivation } \\
\text { took place }\end{array}$ & $\begin{array}{l}\text { MON810 cultivation } \\
\text { prevented }\end{array}$ & $\begin{array}{l}\text { MON810 cultivation took } \\
\text { place }\end{array}$ \\
\hline
\end{tabular}

\subsubsection{Kitzingen: "The Whole District Completely in Uproar" (I15)}

Like everywhere in Germany, farmers in the district of Kitzingen could opt for or against the cultivation of MON810 between 2005 and 2008. As mentioned above, formally, it was only necessary for a farmer to provide notification of the areas designated for cultivation to the Federal Office of Consumer Protection and Food Safety (BVL), which published the registered areas online in the location register ("Standortregister") [46].

Kitzingen is one of the few strongholds of the application of agricultural biotechnology in West Germany and the only district in West Germany where prolonged and intense conflicts over the commercial cultivation of GMOs took place. The conflicts started long before MON810 was approved for cultivation, when field trials were taking place in the region.

When two farmers registered land for commercial GM-maize cultivation, it provoked immediate, very strong local opposition (I21). MON810 cultivation in this district was framed by both supporters and opponents as a (positive or negative) break with the status quo (I5). For those farmers who cultivated MON810, it was a pioneering innovation, while others viewed it as a disruption of traditional GMO-free agriculture and social peace in the villages, a threatening 'invasion' from outside (I17, I25). The question of whether or not GM crops should be cultivated overlapped with concerns about how the conflict would affect patterns of social coexistence (in the village, district, and the wider region) from then on. Advocates of GMOs described GM maize growers as pioneers, while many others saw them as a disruptive force (I18, I20).

Although the conflicts were intense and the resistance to MON810 was strong, registrations of land set aside for its cultivation were listed in the location register for every year from 2005-2008. The number of registrations at the start of the year was always greater than the number of sites where MON810 was actually grown that year; nevertheless, the total area under cultivation grew from year to year. In 2008, a 'field liberation' took place in which protesters destroyed MON810 plants that were 
being grown on a field in the district. Following these intense protests, the total area registered for MON810 cultivation in 2009 (including by an additional, third farmer) was eight times larger than the areas where MON810 was cultivated in 2008. This response illustrates the determination of the GM maize growers in the district.

GMO growers considered that what they were doing was legal, in contrast to the opponents who sometimes resorted to illegal methods, i.e., the field liberations (I18). However, GMO opponents saw these field liberations as legitimate acts of 'civil disobedience' (I15). When MON810 was finally banned in 2009, the official reason given was that new scientific evidence had raised safety concerns [35]. However, the anti-GMO movement celebrated the ban as a political victory (I29, I30). In Kitzingen, the conflicts over agricultural biotechnology were accompanied, especially on the side of the opponents, by a process of politicization. This was something new in the district; many people took part in demonstrations for the first time in their lives. The protest against agricultural biotechnology united a broad social majority and created alliances that did not exist with respect to other policy fields (I29-I31).

Both parties to the conflict were actively supported by regional and national-level actors or were affiliated to them. Two prominent national organizations were the civil disobedience network "Gendreck weg" (which can be roughly translated as "away with genetic rubbish") and "InnoPlanta", a network of supporters of GMOs. In the case of anti-GMO networks, second-order conflicts arose between local actors and external actors. Those involved in the 'field liberations' were mainly non-local actors; local residents were not always supportive of the use of civil disobedience in the conflict, and sometimes expressed disparaging opinions about 'alternative' protest culture (I7, I25). In other cases, a kind of 'division of labor' arose between the local actors and those coming from outside. While local protestors mostly did not participate in acts of civil disobedience, they approved of them and provided logistical support (I10). Several local actors reported that the experience of local conflicts led them to become involved in wider initiatives, opposed to or in favor of GMOs, including Gendreck weg or InnoPlanta (I24, I18, I8, I6). Thus, the distinction between local and non-local (regional and national) actors became blurred.

The politicization that took place also grew in scope to involve debates over, not just GMOs, but also wider questions of how agriculture should be organized. For example, parallel to the protests against GMOs, there were protests against industrialized animal farming [55]. Even after MON810 was banned in 2009, local famers continued to register land for cultivation, in case the ban was overturned, and were part of a coalition of supporters of GMOs that went to court to contest the ban's legality (I8). Protests against agricultural biotechnology also continued in the area. The case of a beekeeper from Kitzingen who went to court to demand compensation for the contamination of his honey by GMOs (due to field trials, not commercial cultivation), and the resulting commercial losses (as the honey could no longer be marketed as GMO-free), was widely reported both nationally and internationally [56].

Overall, the issue has continued to be of topical interest in the area and, according to interviewees, by giving rise to new politicized alliances, acquired a productive, rather than a purely confrontational, dimension (I8, I24, I29, I30). Opponents of cultivation have attempted to declare Kitzingen a GMO-free district, but these efforts have not yet succeeded, which is another sign that the conflicts are ongoing [57].

\subsubsection{Lüchow-Dannenberg: "Wendland Has Defended Itself Successfully”}

This quotation from a speech delivered during a vigil on 15 June 2008 well describes the outcome of the conflict from the perspective of opponents of GMOs. In the district of Lüchow-Dannenberg (also called 'Wendland'), plans to cultivate MON810 that were announced in 2008 immediately ran into difficulties. The presence nearby of the Gorleben radioactive waste disposal facility was already the object of protests by environmental organizations in the area (I22). These protests were still underway in 2008; so when two farmers in the district registered a number of sites for MON810 cultivation, this immediately met with considerable resistance (I26). Opposition to the cultivation of MON810 was 
linked to broader concerns about the threat to the region's identity. One GMO opponent described the cultivation of MON810 as causing "damage to the public image [of the area]" [58].

The protests received widespread support from organizations based outside the area, but were mainly led by local actors (I12-I14). One of the two farmers immediately abandoned his plans to cultivate MON810. The few remaining small areas earmarked for MON810 cultivation belonging to the other farmer were located in a biosphere reserve. Since this was a legally protected area, not only the legitimacy but also the legality of the cultivation was called into question (I12). In expressing their opposition to the proposed cultivation of MON810 in this location, protesters addressed the farmer concerned and the local Monsanto representative personally, including in newspaper advertisements (I12).

On one hand, the conflicts were about agricultural and environmental issues. Many actors were aware of the political dimension of the conflicts and stated explicitly that the decision of whether or not to cultivate GM crops was a political issue (I9, I13, I14). At the same time, the conflicts involved disputes between individual actors; the farmer who wanted to cultivate GM maize and individuals who were opposed to GMOs. The decision by one farmer in the district to sow GM seeds was construed by opponents of GMOs as evidence of a weakness of character or as a personal failure. There was a real sense of personal disappointment in response to the farmer's decision, which was seen by GMO opponents from the village and the wider region as a betrayal (I23). These dimensions, the political and the personal, existed side by side, and the unfolding of the conflict as a whole was characterized by the tension between them.

Protesters held a vigil and occupied the field that was registered for MON810 cultivation. They were unable to prevent MON810 from being sown, but returned after the maize had germinated and uprooted seedlings. Finally, opponents sowed non-GM seed on the field intended for the cultivation of GM maize [59]. This 'preemptive seeding' prevents the sowing of GM seeds, as the area is already 'occupied' by conventional seeds. After this year of intense conflicts, no sites were registered for MON810 cultivation in 2009.

\subsubsection{Oberhavel: "The Setting for a Power Struggle between the Genetically Modified Maize Lobby} and Eco-Anarchists"

This quotation refers to the important role external actors played in conflicts over GMO cultivation in this district. External actors included pro-GMO lobby groups such as InnoPlanta, as well as members of national organizations opposed to genetic engineering (referred to as "eco-anarchists" in the cited end-of-year review in the local newspaper). [60] There was also resistance from local people, but only sporadically (I2, I3). In some cases, even when the protest was initiated by people living in the areas where GMO cultivation took place, it was construed by GMO proponents as the action of 'other' people "who had always been different" in order to maintain Oberhavel's image as a "site of biotechnological innovation" [61]. For example, some proponents of GMOs stated that conflicts only arose when 'incomers' were involved (I11).

In the district of Oberhavel, areas were registered for GMO cultivation as soon as it became possible in 2005. Since most agricultural units in the area are very large (see Supplementary Material 1), there were fewer 'coexistence problems' reported than in other areas; in some cases, there were no neighboring fields at all (I28). However, a beekeeper reported that he moved his hives due to his concerns about GMO contamination (M6). The number of individual farms registering areas for GMO cultivation was comparatively large (10 farms, compared to two in Lüchow-Dannenberg and a maximum of three in Kitzingen). Some of the growers played a prominent role in public life and were strong advocates of GMO cultivation. For others, GMO cultivation was not an ideological decision, but part of a wider strategy to ensure survival of their agricultural holdings (I33-I34, I16).

Some of the Gendreck weg activists sought contact and dialogue with local people, including the farmers who planned to grow MON810. They attempted to engage with what they saw as common concerns about the future of agriculture and made clear that the actions were not meant to address the farmers personally (I15). But in other cases, there was a clear disconnect between village culture and 
the alternative culture of the protesters; during a field liberation that took place in 2006, some residents sat in front of their houses with chairs and umbrellas to observe the anti-GM protests [62].

Second-order conflicts also arose. These related to participants' appreciation of the innate value of agriculture and agricultural work (I16). Some farmers engaged in GMO cultivation saw any criticism of (industrial) agriculture or of specific agricultural practices, e.g., the usage of herbicides, as an inappropriate involvement by non-agricultural actors, who they criticized as failing to appreciate the importance of farming and agricultural products. In the retrospective interviews, proponents cited the fact that MON810 cultivation had been legal until 2008 as a strong argument in favor of its cultivation. They also insisted that farmers should have individual freedom of choice to grow what they want and criticized opponents of GMOs for meddling in their affairs (I16, I33). For the opponents of GMOs, decisions to grow (or not to grow) GMO crops were a societal responsibility, beyond the competence of individual farmers or companies (I19). Overall, the conflicts in Oberhavel did not escalate to the same extent as in the other two districts, and cultivation did not divide the region in the same way, especially as some growers of GM maize were not convinced about the value of the technology (I19). One farmer even switched part of his business to organic farming one year after cultivating GM maize (I34).

Apart from the single field liberation in 2006, the conflicts in Oberhavel were focused around formal decision-making processes. For example, court proceedings were brought to establish both the permitted distance between GM crops and protected natural areas, and the right of property owners to have a say (M5). All this led to Oberhavel district briefly becoming the stage for a national-level conflict about agricultural biotechnology, even though local conflicts did not reach the same intensity as in the other two districts.

\subsection{Conflicts about NBTs in Germany and the UK}

Despite all their potential benefits, it is already becoming apparent that NBTs constitute a new field of conflict. In both Germany and the UK, there is less acceptance of the use of biotechnology in agriculture, which remains highly controversial, than in medicine [63,64]. Government agencies in both countries have initiated dialogues on the topic, including forums organized by the German Federal Ministry of Food and Agriculture, in which possible areas of conflict involving scientists and civil society were discussed [65-67]; a consumer conference on genome editing organized by the German Federal Institute for Risk Assessment (in September 2019) [68]; and, in the UK, a public dialogue launched by the Royal Society [69]. Both proponents and opponents of NBTs in both countries have published position papers. Farmers' unions in Germany and the UK (the National Farmers' Union and the Bauernverband) have adopted similar positions: Both are in favor of the use of NBTs in agriculture and call for regulations that permit their use. The Bauernverband has expressed concern about just one issue; the patenting of plants and animals. Key issues mentioned by both organizations are the need for regulation and for an open debate to counter what they see as the public's distrust of "innovations". The organizations representing small farmers, i.e., the Arbeitsgemeinschaft bäuerliche Landwirtschaft (AbL) in Germany and the Landworkers' Alliance in the UK, also describe regulation as a key issue; however, they call for NBTs to be regulated as GMOs. Interestingly, both the AbL and the Bauernverband justify their contradictory visions as necessary to maintain the competitiveness of farmers and (German and European) agriculture. In line with their former rejection of GMOs, anti-GMO organizations and environmental NGOs from both countries also call for a strict regulation of NBTs as GMOs. They see NBTs as risky technologies. Thus, similar key issues are identified by different groups of actors in both countries. However, organizations in the UK also worry about what is going to happen after Brexit. Some organizations also mention research funding and public participation in decision making about the use of NBTs as key issues. Lobbying organizations that supported the use of GMOs, and the plant breeding companies that developed and sold them, now argue in favor of the use of NBTs and call for them to be more lightly regulated than GMOs. Here also, post-Brexit regulation is an issue for UK organizations. The organic sector in both countries is against the use 
of NBTs as well as GMOs in organic agriculture and claims that NBTs should be regulated as GMOs. Organizations representing organic farmers claim that organic farming offers alternative solutions to the problems NBTs have been developed to solve. Key issues for the organic sector are traceability, labelling, and the notion of agricultural 'innovation'.

The current UK government clearly favors the use of NBTs as part of more general liberalization of regulation. In the UK, the framing of this debate is very much in line with other arguments for and against the EU (and EU regulations). The German government has an ambivalent position: It is not against the use of NBTs and sees them as a promising innovation that should not be rejected immediately. However, the German Government also mentions possible risks and seeks a balance between innovation and precaution. Key issues for both governments are regulation (in the UK, after Brexit) and national competitiveness. Table 2 shows the similarities and differences between the two countries:

Table 2. Similarities and differences between new breeding technique (NBT) conflicts in Germany and the United Kingdom (UK).

\begin{tabular}{ccc}
\hline & Germany & UK \\
\hline Position of farmers' organizations & Pro & Pro \\
Position of environmental NGOs and anti GMO coalitions & Anti & Anti \\
Position of organic sector and small farmers' organizations & Anti & Anti \\
Position of pro GMO coalitions & Pro & Pro \\
Framing by the current government & Innovation vs. & Liberal vs. illiberal \\
& precaution & regulation \\
\hline
\end{tabular}

Overall, the results of the literature review and the document analysis show that support for the use of NBTs goes beyond the biotech industry and also includes national farmers' organizations and the government of both countries. Thus, provided existing regulations are changed, it seems likely that NBTs will be used commercially in agriculture in both countries. In the UK, the outcome will depend on the regulations brought into force after Brexit, assuming that it goes ahead. The future of NBTs in both countries is still open.

\section{Discussion}

The results show the hypotheses have been confirmed and that conflicts over NBTs are at least partly "writing the same old story" [10] as previous conflicts over GMOs, but that they have not yet escalated to the scale or intensity that characterized conflicts over MON810 in Germany between 2005 and spring 2009.

The actor coalitions are very similar to previous conflicts; with opponents of NBTs in civil society organizations on one side and a powerful pro-NBT lobby of agribusiness organizations on the other, while the farming community remains divided and some politicians search for a 'middle way'. Arguments about the pros and cons of NBTs are very similar to those heard in debates over GMOs. Also, as in these previous conflicts, there are debates around whether NBTs will really fulfil the promises that have been made for them [70]. For example, opponents of NBTs have already disputed the claim that NBTs will be accessible to a wider group of actors, i.e., including small and medium sized enterprises in the plant and animal breeding sector, citing key issues connected with patenting and the costs of obtaining approval [71].

The escalation of conflicts over MON810 occurred at a time when increased interest in the topic at national and international levels coincided with the first visible presence of the controversial organisms in the rural landscape. The cultivation sites were transformed into "contested spaces" [72], i.e., time- and location-specific arenas of conflict over GMOs, in which local farmers became key figures, and which were also used as a 'stage' by external (national-level) proponents and opponents of GMOs. The focus of conflict shifted to cultivation areas as a result of actions by both the regulating institutions (i.e., the coexistence policy) and those involved in the conflicts. Abstract debates escalated to a new 
level in response to the material presence, first of the areas designated for GMO cultivation and then, if cultivation took place, of the organisms themselves. There is a parallel here with conflicts over other technologies, which often also come to a head during the implementation phase of specific projects, e.g., about coal mining or the construction of nuclear power plants or nuclear waste disposal facilities (e.g., [73]). In the case of NBTs, although intensive research is taking place, as well as lobbying in favor of their use, the techniques are still a long way from commercial application in both Germany and the UK. Conflict takes place in the realm of research and regulation and is far removed from everyday life, offering few opportunities for members of the public to take part in actions, such as protests and campaigns. But the whole aim of developing NBTs is to apply them for commercial purposes, and for products of NBTs to be used in commercial agriculture. When this happens, the controversial organisms will become visible and tangible. In Germany, there are already the first signs of a possible shift of the arena of conflict to the areas where products of NBTs are likely to be used by farmers. In the district of Kitzingen, for instance, where the cultivation of crop varieties produced by NBTs would be likely because of the powerful actor coalition in the area in favor of GMOs, NBTs are already on the agenda of opponents of GMOs [74].

The issue of GMOs and NBTs is a striking example of conflictive society-nature relations as described in Political and Social Ecology. GMOs and the products of NBTs are socially and technically produced and yet at the same time 'natural' and alive. Whether to use them or not is a matter of how 'nature' is engaged with and of how society-nature relations are shaped. In Germany, conflicts over MON810 had discursive and material dimensions. Expressions of opinion through language (e.g., by writing position papers) were just as much actions in the conflicts as those that affected society-nature relations on a material level. The latter included controversial farming practices, i.e., GMO cultivation and GMO-free agriculture, as well as some of the more radical protests against GMO cultivation, such as 'field liberations' and 'pre-emptive seeding'. These conflicts over the cultivation of MON810 contributed to changing the future of agricultural biotechnology in Germany, at least for the time being. At the same time, they transformed the areas where they took place. More generally, the conflicts highlighted the inherent difficulty of implementing the EU's policy of 'coexistence'. It became clear during the course of the conflicts that this is not only because of the threat of contamination of GM-free areas, but also due to mutual incompatibility of conflicting visions of the future of agriculture. For proponents of GMOs, they symbolize 'innovative' agriculture; for opponents they symbolize all that is wrong with 'industrialized' agriculture. A similar 'broadening out' of conflicts over GMOs has also been reported for other countries, e.g., Spain [75].

It can be expected that there will be a repetition of these processes once NBTs are ready to be applied commercially. An area of uncertainty is how the (partial) absence of traceability, i.e., the means to distinguish products of NBTs from those of conventional breeding techniques, will limit the 'transfer' of forms of protest developed during the conflicts over GMOs. In principle, the absence of traceability could invalidate not only field liberations, but also the establishment of GMO-free regions or municipalities [76,77]. Another open question is how it might affect the nature and scale of protest activities when the organisms concerned are not plants, but animals.

In the period 2005-2009, Germany was increasingly divided into genetic engineering hot spots and GMO-free areas [46]. The hotspots were areas deemed suitable for GM cultivation, because of the structure of agriculture (i.e., large-scale farms), social conditions (i.e., low levels of protest in the region and/or very determined GM growers), or the absence of protected natural areas. The three cases show that the outcome could be influenced by just one of these determinants. In Kitzingen, for instance, MON810 cultivation took place despite the predominance of small-scale agriculture in the district, which made it more difficult to comply with 'distance rules', i.e., the distances between GM crops and GMO-free fields prescribed by the policy of 'coexistence', and despite ongoing intense protests. The determination of the GMO growers was sufficient to ensure continuous cultivation. Since 2009, the division between GMO and GMO-free agriculture has continued in Germany, but less visibly and at a different scale; only commercial cultivation was banned, while the import of genetically modified 
animal feed, produced in other parts of the word, e.g., the USA or Argentina, continues, in accordance with EU policy [31]. These regional and global divisions could be reproduced in future conflicts over NBTs. Thus, it is likely that attempts will be made to find 'suitable' locations for application of NBTs as a way of avoiding conflicts over more general questions about the future of agriculture. But as was the case, at least to some extent in the conflicts over MON810, a politicization of the conflicts could also occur, leading to discussion of wider issues beyond the simple question: "NBTs: yes or no?" The politicization of conflict is seen as a positive development from the viewpoint of Social and Political Ecology $[50,51]$. This process could be derailed, as also occurred in the conflicts over MON810, if personal disputes come to the fore, leading to an individualization of the conflict, rather than its politicization.

At the level of policy, several different possible future pathways for the policy frameworks in the UK and Germany can be identified. A first path would be continuing regulation of NBTs as GMOs in both countries. Considering all the unresolved concerns surrounding GMOs, this would make approval of NBTs for commercial use unlikely in the foreseeable future. A second pathway would involve regulation of some or all NBTs or their products as traditional agriculture, i.e., not as GMOs, in one or both countries. That change could take place at the EU level and/or in the UK after Brexit. By highlighting the technical differences between NBTs and first generation GMOs, this could lead to NBTs being seen as less controversial. This is how the issue is currently being framed by proponents of NBTs. However, the evidence suggests that there are strong coalitions of actors who would refuse to accept NBTs however they are framed by policy makers. The third pathway, which is perhaps most likely, would involve a divergence of regulation both within Europe and between the EU and the rest of the world: for example, pro-NBT regulation in the UK after Brexit and continuing 'anti-NBT' regulation in the EU. For now, at least, the use of the commercial application of NBTs seems less likely in Germany than in the UK, because of the innovation-friendly policy and deregulatory agenda of the current UK government and predictions of a general move towards regulatory liberalism in the UK after Brexit. However, it is also possible that there will be a divergence of regulation within the EU in response to calls for more liberal regulation and for individual member states to be given more regulatory power over the use of GMOs [78]. That could lead to the development of 'NBT hotspots' located in particular EU countries. All these policy pathways will remain open until commercial application is authorized (or definitively rejected) in different European countries. This will also be the moment that shifts practice onto different pathways, closing off other alternatives, but also opening up alternative pathways of conflict. Whatever happens, the analysis of conflicts over MON810 strongly suggests that conflicts over NBTs will escalate to a higher level if and when commercial application of NBTs begins, and will be most intense where products of NBTs are a visible and tangible presence in rural areas.

\section{Outlook}

The role that NBTs should or should not play in the transformation of agricultural systems towards sustainability is as contested as the concept of sustainability itself. Critical sustainability science from the perspective of Social and Political Ecology can provide crucial insights for the analysis of conflicts over NBTs and their links to wider conflicts over environmental issues and sustainability. In particular, this perspective highlights the interlinkage between discursive and material dimensions of the conflicts. It is clear that the conflicts are about much more than the manipulation of organisms and possible environmental impacts; they also have a societal dimension. At the same time, if the concern is to leave open alternative pathways to sustainability, e.g., through GMO-free agriculture, it is precisely the inherent uncertainty of material dimension that has to be born in mind. The impossibility of a total domination and control of 'nature', which NBTs still are despite being the product of human technology, means that the precautionary principle should play a central role in decision making regarding both policy and practice [51]. Moreover, since conflicts over breeding techniques such as NBTs are also conflicts about society-nature relations, they are inseparable from ethical considerations and wider 
conflicts over power relations and other social issues. These include the key issue of who does and who does not have a say in decision making about the future of NBTs adoption or rejection $[79,80]$. In this sense, a challenge will be to find suitable arenas to negotiate the future of NBTs.

The analysis shows that, if commercialization of NBTs takes place, trajectories of conflict, at the level of policy, could lead to the emergence of territorial divisions at different scales between NBT hot spots and NBT-free areas. Commercial application could have an immense impact on social relations (as well as ecosystems) in the areas where NBTs are used, giving rise to conflicts in these areas. These could be derailed into personalized conflicts and local disputes about the suitability of particular areas for NBTs. However, there are already calls, for example, from NGOs, to "open up debate and discussion on the role of emerging technologies, such as genome editing, and the future of agriculture and food sovereignty" [81]. These demonstrate the potential for a politicization of the conflicts over NBTs to encompass wider issues related to transformation of agricultural systems towards sustainability.

Supplementary Materials: The following are available online at http://www.mdpi.com/2071-1050/12/1/144/s1. Agricultural structure in the districts of Kitzingen, Lüchow-Dannenberg, and Oberhavel [82], Code system, codes per interview (I1-I34, MAXQDA) and information about the interviewees, List of documents (NBT conflicts in the UK and Germany).

Funding: This research was funded by Deutsche Forschungsgemeinschaft (DFG), grant number FR 4225/1-1, project number 424882341. The empirical study of conflicts over MON810 in Germany was funded by the German Federal Ministry of Education and Research (BMBF), grant number PoNa 01UU0903.

Acknowledgments: I wish to thank the editors and reviewers for their specific and careful comments to improve the text. I am also very grateful to Andrew Halliday for his language editing support and wish to thank my hosts and colleagues from the University of Sussex, Brighton, UK, for their comments on an earlier version of this text and many inspirations.

Conflicts of Interest: The author declares no conflict of interest. The funders had no role in the design of the study; in the collection, analyses, or interpretation of data; in the writing of the manuscript, or in the decision to publish the results.

\section{References}

1. Falkner, R. (Ed.) The International Politics of Genetically Modified Food. Diplomacy, Trade, and Law; Palgrave Macmillan: London, UK, 2007.

2. Maina, A. GMOs and the Politics of Food in Africa; Chain Reaction: Ballyclare, UK, 2011; pp. 16-18.

3. Herrero, A.; Binimelis, R.; Wickson, F. Just Existing Is Resisting: The Everyday Struggle against the Expansion of GM Crops in Spain. Sociol. Rural. 2017, 57, 859-880. [CrossRef]

4. Newell, P. Food for the Few. Neoliberal Globalism and Biotechnology in Latin America, 1st ed.; Otero, G., Ed.; University of Texas Press: Austin, TX, USA, 2008.

5. ISAAA-International Service for the Acquisition of Agri-Biotech Applications. Global Status of Commercialized Biotech/Gm Crops in 2018. Available online: http://www.isaaa.org/resources/publications/ briefs/54/executivesummary/pdf/B54-ExecSum-English.pdf (accessed on 16 December 2019).

6. GfK (Growth for Knowledge). Low-Sugar and GMO-Free Are Top Factors when Deciding what to Eat or Drink. Available online: http://www.gfk.com/global-studies/global-studies-decision-factors-on-what-to-eatand-drink/ (accessed on 30 November 2019).

7. Bundesministerium für Umwelt, Naturschutz und nukleare Sicherheit (BMU); Bundesamt für Naturschutz (BfN). Naturbewusstsein 2017. Bevölkerungsumfrage zu Natur und biologischer Vielfalt. 2018. Available online: https://www.bmu.de/fileadmin/Daten_BMU/Pools/Broschueren/naturbewusstseinsstudie_2017_de_ bf.pdf (accessed on 30 November 2019).

8. Levidow, L.; Boschert, K. Coexistence or contradiction? GM crops versus alternative agricultures in Europe. Geoforum 2008, 39, 174-190. [CrossRef]

9. Catacora-Vargas, G.; Binimelis, R.; Myhr, A.I.; Wynne, B. Socio-economic research on genetically modified crops: A study of the literature. Agric. Hum. Values 2018, 9, 91. [CrossRef]

10. Wickson, F; Binimelis, R.; Herrero, A. Should Organic Agriculture Maintain Its Opposition to GM: New Techniques Writing the Same Old Story. Sustainability 2016, 8, 1105. [CrossRef] 
11. Sprink, T.; Eriksson, D.; Schiemann, J.; Hartung, F. Regulatory hurdles for genome editing: Process- vs. product-based approaches in different regulatory contexts. Plant Cell Rep. 2016, 35, 1493-1506. [CrossRef] [PubMed]

12. Bertheau, Y. New Breeding Techniques: Detection and Identification of the Techniques and Derived Products. In Encyclopedia of Food Chemistry; Varelis, P., Melton, L., Shahidi, F., Eds.; Elsevier Science: Amsterdam, The Netherlands, 2018; pp. 320-336.

13. Giese, B.; Frieß, J.L.; Preu, M.; Then, C.; Lalyer, C.R.; Breckling, B.; Schröder, W.; von Gleich, A. Gene Drives. Potenziale, Risiken, Besorgnisgründe. Ergebnisbericht des Pilot-Projekts GeneTip - Genetische Innovationen als Auslöser für Phasenübergänge in Populationsdynamiken von Tieren und Pflanzen. 2019. Available online: https://www.genetip.de/wp-content/uploads/GeneTip_Endbericht.pdf (accessed on 30 November 2019).

14. Yuan, Y.; Scheben, A.; Batley, J.; Edwards, D. Using Genomics to Adapt Crops to Climate Change. In Sustainable Solutions for Food Security: Combating Climate Change by Adaptation; Sarkar, A., Sensarma, S.R., vanLoon, G.W., Eds.; Springer International Publishing: Berlin/Heidelberg, Germany, 2019; pp. 91-109.

15. Lillico, S. Agricultural applications of genome editing in farmed animals. Transgenic Res. 2019, $28,57-60$. [CrossRef]

16. Phelps, M.P.; Seeb, L.W.; Seeb, J.E. Transforming ecology and conservation biology through genome editing. Conserv. Biol. 2019. [CrossRef]

17. Friedrich, B.; Hackfort, S.K. Konfliktfeld neue Gentechnik: Regulierung landwirtschaftlicher Biotechnologien zwischen Innovation und Vorsorge. GAIA 2018, 27, 211-215. [CrossRef]

18. Seyran, E.; Craig, W. New breeding techniques and their possible regulation. AgBioForum 2018, 21, 1-12.

19. Hartley, S.; Gillund, F.; van Hove, L.; Wickson, F. Essential Features of Responsible Governance of Agricultural Biotechnology. PLoS Biol. 2016, 14, e1002453. [CrossRef]

20. United Nations Environment Programme (UNEP). Frontiers 2018/19. Emerging Issues of Environmental Concern. 2019. Available online: https://wedocs.unep.org/bitstream/handle/20.500.11822/27538/Frontiers1819.pdf? sequence $=1 \&$ isAllowed $=y$ (accessed on 19 December 2019).

21. Friedrichs, S.; Takasu, Y.; Kearns, P.; Dagallier, B.; Oshima, R.; Schofield, J.; Moreddu, C. Policy Considerations Regarding Genome Editing. Trends Biotechnol. 2019, 37, 1029-1032. [CrossRef] [PubMed]

22. Winter, G. Alte und neue Kämpfe ums Gentechnikrecht. GAIA 2017, 26, 73-160. [CrossRef]

23. Corperate Europe Observatory. EFSA Gene Drive Working Group Fails Independence Test. Available online: https://corporateeurope.org/en/2019/06/efsa-gene-drive-working-group-fails-independence-test (accessed on 30 November 2019).

24. Deutscher Bundestag. Antwort der Bundesregierung auf die Kleine Anfrage der Abgeordneten Harald Ebner, Dr. Anna Christmann, Kai Gehring, weiterer Abgeordneter und der Fraktion BÜNDNIS 90/DIE GRÜNEN-Drucksache 19/7250-Forschungsförderung des Bundes für die Agrogentechnik inklusive neuer Gentechnikverfahren. Drucksache19/7926. 2019. Available online: http://dip21.bundestag.de/dip21/btd/19/ 079/1907926.pdf (accessed on 30 November 2019).

25. ECJ. Judgement of the Court (Grand Chamber). Case C-528/16. 2018. Available online: http://curia. europa.eu/juris/document/document.jsf;jsessionid=9ea7d0f130da42d9e43d74164c6d9a7497e6727643bb. e34KaxiLc3eQc40LaxqMbN4Pb3uMe0?text=\&docid=204387\&pageIndex=0\&doclang=EN\&mode=req\& dir $=\&$ occ $=$ first $\&$ part $=1 \&$ cid $=39917$ (accessed on 30 November 2019).

26. Gelinsky, E.; Hilbeck, A. European Court of Justice ruling regarding new genetic engineering methods scientifically justified: A commentary on the biased reporting about the recent ruling. Environ. Sci. Eur. 2018, 30, 1-9. [CrossRef]

27. European Food \& Feed Cultures Association (EFFCA). Over 20 EU Business Associations Call for Innovation-Friendly Rules on Mutagenesis. Available online: https:/effca.org/publications/over-20-eubusiness-associations-call-for-innovationfriendly-rules-on-mutagenesis/ (accessed on 30 November 2019).

28. Fortuna, G. 14 EU Countries Call for 'Unified Approach' to Gene Editing in Plants. Available online: https://www.euractiv.com/section/agriculture-food/news/14-eu-countries-call-for-unified-approachto-gene-editing-in-plants/ (accessed on 30 November 2019). 
29. European Union. COUNCIL DECISION (EU) 2019/1904 of 8 November 2019 Requesting the Commission to Submit a Study in Light of the Court of Justice's Judgment in Case C-528/16 Regarding the Status of Novel Genomic Techniques under Union Law, and a Proposal, if Appropriate in View of the Outcomes of the Study. Available online: https:/eur-lex.europa.eu/legal-content/EN/TXT/PDF/?uri=CELEX:32019D1904\&from=EN (accessed on 30 November 2019).

30. Department for Environment, Food \& Rural Affairs (DEFRA). Genetically Modified Organisms: Applications and Decisions: Information about the Release of Genetically Modified Organisms (GMOs) for Research Purposes Application and Consent Process. Available online: https://www.gov.uk/government/collections/ genetically-modified-organisms-applications-and-consents (accessed on 30 November 2019).

31. Bundesministerium für Verbraucherschutz und Lebensmittelsicherheit (BVL). Gentechnik—Sorgfältig Prüfen, Sicher Zulassen. Available online: https://www.bvl.bund.de/DE/06_Gentechnik/gentechnik_node.html (accessed on 30 November 2019).

32. Gov.Uk. Importing Food. Available online: https://www.gov.uk/food-safety-as-a-food-distributor/ genetically-modified-foods (accessed on 30 November 2019).

33. European Commission. Restrictions of Geographical Scope of GMO Applications/Authorisations: EU Countries Demands and Outcomes. Available online: https:/ec.europa.eu/food/plant/gmo/authorisation/ cultivation/geographical_scope_en\#dk (accessed on 30 November 2019).

34. Bundesministerium für Ernährung und Landwirtschaft. Grüne Gentechnik. Available online: https://www. bmel.de/DE/Landwirtschaft/Pflanzenbau/Gentechnik/gentechnik_node.html (accessed on 30 November 2019).

35. BVL (Bundesamt für Verbraucherschutz und Lebensmittelsicherheit). Bescheid an Monsanto Europe S.A. Vom 17.04.2009. 2009. Available online: http://www.bvl.bund.de/SharedDocs/Downloads/08_PresseInfothek/ mon_810_bescheid.pdf?_blob=publicationFile (accessed on 30 November 2019).

36. Kuhr, D. Das Ende der Gen-Kartoffel in Europa. Süddeutsche Zeitung. 16 January 2012. Available online: https://www.sueddeutsche.de/wirtschaft/basf-stellt-amflora-anbau-ein-das-ende-der-gen-kartoffelin-europa-1.1259527 (accessed on 30 November 2019).

37. Drückmann, F. Krieg in den Dörfern und auf den Feldern? Zur Politischen Geographie der Grünen Gentechnik. Geogr. Rundsch. 2011, 2, 12-20.

38. Friedrich, B. Der ganze Landkreis komplett in Aufruhr: Konflikte um Agro-Gentechnik 2005 bis 2009 : Theoretische Perspektiven und empirische Ergebnisse. Z. Agrargesch. Agrarsoziol. 2017, 65, 75-89.

39. Kuntz, M. Destruction of public and governmental experiments of GMO in Europe. GM Crops Food 2012, 3, 258-264. [CrossRef] [PubMed]

40. Doherty, B.; Hayes, G. Tactics, traditions and opportunities: British and French crop-trashing actions in comparative perspective. Eur. J. Politi. Res. 2012, 51, 540-562. [CrossRef]

41. Animal and Plant Health Agency. Annual Report on GMO Inspection and Enforcement Activities in England. 1 April 2014-31 March 2015. Available online: https://assets.publishing.service.gov.uk/government/uploads/ system/uploads/attachment_data/file/521828/GMI-annual-report1415.pdf (accessed on 30 November 2019).

42. Deutscher Bundestag. Neue Pflanzenzüchtungstechniken in der Landwirtschaft. Rechtliche Rahmenbedingungen für die Erforschung, Freisetzung und Kennzeichnung/Auswirkungen auf den Saatgutmarkt. 2018. Available online: https://www.bundestag.de/resource/blob/571486/ 2ae09ab5da741b75ec7ab6dfaf0cc02d/wd-5-103-18-pdf-data.pdf (accessed on 19 December 2019).

43. Faure, J.-D.; Napier, J.A. Europe's first and last field trial of gene-edited plants? eLife 2018, 7. [CrossRef]

44. BVL (Bundesamt für Verbraucherschutz und Lebensmittelsicherheit). Cibus Raps-Bescheid vom BVL Zurückgenommen. Available online: https://www.bvl.bund.de/SharedDocs/Fachmeldungen/06_gentechnik/ 2018/2018_08_17_Fa_Cibus_Raps_Bescheid.html (accessed on 30 November 2019).

45. John Innes Centre. Application for Field Trial of Genetically Modified Organisms: High Iron Wheat and CRISPR Brassica. Available online: https://www.jic.ac.uk/news/application-field-trial-2019/ (accessed on 30 November 2019).

46. BVL (Bundesamt für Verbraucherschutz und Lebensmittelsicherheit). Standortregister. Available online: http://apps2.bvl.bund.de/stareg_web/showflaechen.do (accessed on 16 December 2019).

47. Strauss, A.; Corbin, J. Grounded Theory. Grundlagen Qualitativer Sozialforschung; Beltz Psychologie Verl.-Union: Weinheim, Germany, 1996. 
48. Mayring, P. Qualitative Content Analysis: Theoretical Foundation, Basic Procedures and Software Solution. 2014. Available online: https://www.ssoar.info/ssoar/bitstream/document/39517/1/ssoar-2014-mayringQualitative_content_analysis_theoretical_foundation.pdf (accessed on 30 November 2019).

49. Hsieh, H.-F.; Shannon, S.E. Three approaches to qualitative content analysis. Qual. Health Res. 2005, 15, 1277-1288. [CrossRef]

50. Le Billon, P. Environmental Conflict. In The Routledge Handbook of Political Ecology; Perreault, T., Bridge, G., McCarthy, J., Eds.; Routledge: London, UK, 2015; pp. 598-608.

51. Friedrich, B.; Hackfort, S.; Boyer, M.; Gottschlich, D. Conflicts over GMOs and their Contribution to Food Democracy. PagSeguro 2019, 7, 165. [CrossRef]

52. LeBillon, P.; Duffy, R.V. Conflict ecologies: Connecting political ecology and peace and conflict studies. J. Politi. Ecol. 2018, 25, 239. [CrossRef]

53. Hummel, D.; Jahn, T.; Keil, F.; Liehr, S.; Stieß, I. Social Ecology as Critical, Transdisciplinary Science-Conceptualizing, Analyzing and Shaping Societal Relations to Nature. Sustainability 2017, 9, 1050. [CrossRef]

54. Preston, C.J.; Wickson, F. Broadening the lens for the governance of emerging technologies: Care ethics and agricultural biotechnology. Technol. Soc. 2016, 45, 48-57. [CrossRef]

55. Haass, R. Das größte Risiko der Menschheit. Mainpost. 24 February 2008. Available online: https: //www.mainpost.de/regional/kitzingen/Das-groesste-Risiko-der-Menschheit (accessed on 18 April 2011).

56. Gerichtshof der Europäischen Union. Pressemitteilung Nr. 79/11 vom 6. September 2011: Honig und Nahrungsergänzungsmittel, die den Pollen eines GVO enthalten, sind aus GVO hergestellte Lebensmittel, die nicht ohne vorherige Zulassung in den Verkehr gebracht werden dürfen; Presse und Information Urteil in der Rechtssache C-442/09, Karl Heinz Bablok u. a./Freistaat Bayern. 2011. Available online: https://curia.europa.eu/jcms/ upload/docs/application/pdf/2011-09/cp110079de.pdf (accessed on 19 December 2019).

57. Gentechnikfreie Regionen. GMO-Free Regions and Municipalities in Germany. Available online: https: //www.gentechnikfreie-regionen.de/themen/regionen-und-initiativen/english/ (accessed on 30 November 2019).

58. Elbe-Jeetzel-Zeitung. BUND lehnt Genmaisanbau bei Laase ab. Elbe-Jeetzel-Zeitung, 25 April 2008.

59. Bündnis Gentechnikfreies Wendland. Es ist nicht mehr nötig den großen Acker in einer Öffentliche Feldbefreiungsaktion zu befreien. Available online: http://gentechnik-im-wendland.blogspot.com/search? updated-max=2008-06-15T12:51:00\%2B02:00\&max-results=6\&start $=24 \&$ by-date $=$ false $($ accessed on 30 November 2019).

60. Neues Granseer Tageblatt. Totenschädel, Kräuterquark und Genmais: Vom Kampf gegen Vogelgrippe, Grubenmüll und Umleitungen: Aufregendes aus dem Archiv. Neues Granseer Tageblatt, 29 December 2006.

61. Bickel, K.M.Z. Widerstand gegen Genmais wächst, 11. Februar, Seite 14, Gentechnik würde Oberhavel nützen: Letter to the editor. Neue Oranienburger Zeitung, 26 February 2005.

62. Hollmichel, V. Ein Tag im Maisfeld. Taz-Die Tageszeitung Vom 01.08.2006. 2006. Available online: http://www.taz.de/1/archiv/archiv/?dig=2006/08/01/a0208 (accessed on 30 November 2019).

63. BfR (Bundesinstitut für Risikobewertung). Durchführung von Fokusgruppen zur Wahrnehmung des Genome Editings CRISPR/Cas9. 2017. Available online: http://www.bfr.bund.de/cm/350/durchfuehrungvon-fokusgruppen-zur-wahrnehmung-des-genome-editings-crispr-cas9.pdf (accessed on 30 November 2019).

64. Gaskell, G.; Allum, N.; Bauer, M.; Jackson, J.; Howard, S.; Lindsey, N. Ambivalent GM Nation? Public Attitudes to Biotechnology in the UK, 1991-2002; Life Sciences in European Society Report; London School of Economics and Political Science: London, UK, 2003.

65. BMEL (Bundesministerium für Ernährung und Landwirtschaft). Die Anwendung des Genome Editing in Forschung und Praxis: 1. Dialogveranstaltung zu den Neuen Molekularbiologischen Techniken. Available online: https://www.bmel.de/SharedDocs/Downloads/Landwirtschaft/Pflanze/GrueneGentechnik/ Dokumentation_Dialogveranstaltung_NMT.pdf?_blob=publicationFile (accessed on 30 November 2019). 
66. BMEL (Bundesministerium für Ernährung und Landwirtschaft). Innovation verantwortlich gestalten. 3. Dialogveranstaltung $\mathrm{zu}$ den Neuen Molekularbiologischen Techniken. Zusammenfassende Dokumentation der Veranstaltung. 2017. Available online: https://www.bmel.de/SharedDocs/Downloads/ Landwirtschaft/Pflanze/GrueneGentechnik/Dokumentation_3_Dialogveranstaltung_NMT.pdf;jsessionid= 3534F1776B300E6CE4D3888A0ABC75C9.2_cid376?_blob=publicationFile (accessed on 30 November 2019).

67. BMEL (Bundesministerium für Ernährung und Landwirtschaft). Kriterien für einen verantwortungsvollen Umgang mit Genome Editing: 2. Dialogveranstaltung zu den Neuen Molekularbiologischen Techniken. Available online: http://www.bmel.de/SharedDocs/Downloads/Landwirtschaft/Pflanze/GrueneGentechnik/ Dokumentation_2_Dialogveranstaltung_NMT.pdf?_blob=publicationFile (accessed on 30 November 2019).

68. Bundesinstitut für Risikobewertung. Conclusion of the BfR Consumer Conference on Genome Editing: Lots of Potential, but Clear Rules Required. Available online: https: //www.bfr.bund.de/en/press_information/2019/35/conclusion_of_the_bfr_consumer_conference_on_ genome_editing_lots_of_potential_but_clear_rules_required-242324.html (accessed on 30 November 2019).

69. Smith, R.D.J.; Samuel, G. Who's Talking about non-Human Genome Editing? Mapping Public Discussion in the UK. Available online: http://www.stis.ed.ac.uk/_data/assets/pdf_file/0014/252212/Smith_and_Samuel_ 2018_NH_Gene_editing_review_Final.pdf (accessed on 30 November 2019).

70. Deutscher Naturschutzring. Neue Gentechnik. Des Kaisers neue Kleider? 2019. Available online: https://www.dnr.de/fileadmin/Publikationen/Steckbriefe_Factsheets/19_05_23_Steckbrief_ Gentechnik_.pdf (accessed on 30 November 2019).

71. Testbiotech. Patent Cartel for the Large Companies. Introduction of Genome Editing Accelerates Process of Market Concentration in Breeding. 2019. Available online: Https://www.testbiotech.org/en/news/patentcartel-large-companies (accessed on 30 November 2019).

72. Woods, M. Engaging the global countryside: Globalization, hybridity and the reconstruction of rural place. Prog. Hum. Geogr. 2007, 31, 485-507. [CrossRef]

73. Morris, C.; Jungjohann, A. The Birth of a Movement: 1970s Protests for Democracy in Wyhl. In Energy Democracy: Germany's Energiewende to Renewables; Morris, C., Jungjohann, A., Eds.; Springer International Publishing: Berlin/Heidelberg, Germany, 2016; pp. 15-36.

74. Weichhan, F. Vor zehn Jahren: Kitzingen als Genmais-Kampfgebiet. Mainpost. 28 August 2019. Available online: https://www.mainpost.de/regional/kitzingen/Vor-zehn-Jahren-Kitzingen-als-Genmais-Kampfgebiet; art773,10303365 (accessed on 30 November 2019).

75. Binimelis, R. Coexistence of Plants and Coexistence of Farmers: Is an Individual Choice Possible? J. Agric. Environ. Ethics. 2008, 21, 437-458. [CrossRef]

76. Tosun, J.; Shikano, S. GMO-free regions in Europe: An analysis of diffusion patterns. J. Risk Res. 2016, 19, 743-759. [CrossRef]

77. Hartung, U.; Schaub, S. The Regulation of Genetically Modified Organisms on a Local Level: Exploring the Determinants of Cultivation Bans. Sustainability 2018, 10, 3392. [CrossRef]

78. Salvi, L. The EU Regulatory Framework on GMOs and the Shift of Powers towards Member States: An Easy Way Out of the Regulatory Impasse? Eur. Food Feed Law Rev. 2016, 11, 201-210.

79. Malyska, A.; Bolla, R.; Twardowski, T. The Role of Public Opinion in Shaping Trajectories of Agricultural Biotechnology. Trends Biotechnol. 2016, 34, 530-534. [CrossRef]

80. Pollock, C.J. How Should Risk-Based Regulation Reflect Current Public Opinion? Trends Biotechnol. 2016, 34, 604-605. [CrossRef]

81. Helliwell, R.; Hartley, S.; Pearce, W. NGO perspectives on the social and ethical dimensions of plant genome-editing. Agric. Hum. Values 2019, 36, 779-791. [CrossRef]

82. Friedrich, B. Das Konfliktfeld Gesellschaftliche Naturverhältnisse am Beispiel von Agro-Gentechnik. Eine Fallstudie in den Landkreisen Kitzingen, Lüchow-Dannenberg und Oberhavel. Ph.D. Thesis, Leuphana Universität Lüneburg, Lüneburg, Germany, 2015; p. 112.

(C) 2019 by the author. Licensee MDPI, Basel, Switzerland. This article is an open access article distributed under the terms and conditions of the Creative Commons Attribution (CC BY) license (http://creativecommons.org/licenses/by/4.0/). 